\title{
An Econometric Analysis of Tax Evasion and Its Consequences on Economic Performance
}

\author{
Abdullah M. Ghazo ${ }^{1}$, Qusay M. Qasrawi ${ }^{2 *}$, Ziad M. Abu-Lila ${ }^{1}$ \\ ${ }^{1}$ Faculty of Economics and Administrative Sciences Department of Economics of Finance and Business Al al-Bayt University P.O. Box \\ 130040, 25113 Mafraq, Jordan \\ ${ }^{2}$ Trade Analyst United Nations Development Programme P.O. Box 852303, 11185 Amman, Jordan
}

\begin{abstract}
This study aimed to estimate the extent of tax evasion in Jordan based on a currency demand methodology, the results of the time series stationarity test showed that there was a time series to be non-stationary at the same degree, and the results of the co-integration test showed the existence of co-integration between the model variables, the size of tax evasion during the period 1980 2019 was estimated using the fully modified ordinary least squares method (FM-OLS).The results showed that the average rate of tax evasion as a percentage of (GDP) amounted to $2.7 \%$, whereas it reached $16.7 \%$ of tax revenues, After the extent of tax evasion had been estimated, its impact on some macroeconomic variables was identified through the Toda and Yamamoto causality test, This test showed that tax evasion had an impact on the general consumer price index, GDP, tax revenues, public debt, both public and private investment, and both public and private consumption, Finally the study recommends that more attention should be paid to the tax evasion phenomenon by officials in charge of economic policies and tax administration in order to reduce tax evasion and its impact on the economic variables and, thus, achieve greater economic stability.
\end{abstract}

\section{Keywords:}

Econometric Analysis;

Tax Evasion; FM-OLS;

Consequences;

Toda and Yamamoto.

\section{Article History:}

Received: 08 January 2021

Revised: 11 March 2021

Accepted: 19 March 2021

Published: $01 \quad$ April 2021

\section{1- Introduction}

The phenomenon of tax evasion coincides with the existence of taxes and their expansion as some individuals and institutions begin to move from the formal economy to the shadow economy to escape those taxes, especially if the economy is suffering from modest investment and low employment rates due to the decline in the demand for goods and services and the high costs of production. The phenomenon of tax evasion is one of the challenges that officials in charge of economic policies and tax administration and their collectors face, especially when the state suffers from low revenue and high spending bills while needing to provide infrastructure and public services in order to achieve economic development. If national governments fail to collect all their expected tax revenues as a result of tax avoidance or tax evasion, they will face additional deficits in their budgets, which may lead decision-makers in those countries to impose more taxes and expand the tax base, or they may increase borrowing to compensate for the shortfall in revenue. Because of the need to finance public expenditure, and with the increase in the demand for cash in circulation (in order to complete business operations in cash) that accompanies tax evasion, this may lead to a rise in the interest rate, a rise in prices and, consequently, a decrease in the domestic demand for consumers as well as the investment in goods and services. As a result of the decline in the purchasing power of individuals, the resulting increase in tax evasion and the move to the shadow economy by individuals or companies, the economy remains in a vicious circle that may lead to a decline in

\footnotetext{
*CONTACT: Qasrawi85@hotmail.com
}

DOI: http://dx.doi.org/10.28991/esj-2021-01271

(C) 2021 by the authors. Licensee ESJ, Italy. This is an open access article under the terms and conditions of the Creative Commons Attribution (CC-BY) license (https://creativecommons.org/licenses/by/4.0/). 
economic growth rates which prevents the state from achieving acceptable rates of economic development and creates new economic distortions. In addition, there would be some social problems that may result from the general decline in the economy.

Consequently, dealing with the issue of tax evasion and studying its economic and social consequences has recently become a key topic which captures the attention of researchers and economic policymakers as the estimation of the extent of tax evasion and of the resulting economic and social costs helps economic policymakers understand the reliability and effectiveness of the tax system, its characteristics, and its impact on economy as a whole. In the next section, we briefly review the findings of the theoretical literature which is concerned with methods of estimating tax evasion and the most important factors that lead to tax evasion. In section III, an empirically testable model of estimating tax evasion is specified. Section IV discusses the consequences of tax evasion. The final section contains some concluding comments.

\section{2- Literature Review}

Economic opinions unanimously agree that tax evasion is often measured through the shadow economy ( hidden economy), which is defined as that part of the gross domestic product (GDP) that is not declared for any reason and is not included in the official statistics [1]. Therefore, this part of GDP is generally not subject to any form of taxation, and this is the main link between hidden economic activity and tax evasion: it is defined as that part of the shadow economy that, if it were declared, would have been entered into the official burden of tax [2]. It is also known as the illegal behavior that a taxpayer perpetrates by circumventing tax laws in order not to pay some or all of the tax they owe [3]. Furthermore, it can be known as the illegal use of the tax system that intentionally avoids paying the actual tax owed. This differs from tax avoidance, which is defined as the legal use of the tax system for the benefit of individuals or institutions to reduce the amount of tax due through the law. The government may allow tax avoidance in order to achieve certain economic and social goals, such as reducing the tax on the profits of some sectors to encourage investors to invest in those sectors. Thus, tax avoidance differs from tax evasion only regarding legal cover, whereas they share economic and social effects [4]. Determining the actual value of tax evasion is difficult; it cannot be measured directly due to its illegal nature, which necessitates secrecy, and due to the difficulty of accessing its data. However, there are several indirect methods that can be used to estimate its size, which often depend on estimating the shadow economy first and estimating tax evasion afterwards. Some of these methods are outlined below.

The expenditure-income discrepancy approach: is based on the existence of discrepancies in different estimates of GDP, according to whether the estimate is produced by the expenditure approach or the income approach. The existence of the discrepancy is due to the existence of the shadow economy [5,6]. The physical approach method: is based on the idea of a relationship between the use of specific inputs, such as the number of electricity units used in production, and the value of production. For example, when the actual value of the number of electricity units used in production is higher than the actual value of production disclosed, this indicates the existence of a shadow economy [7]. The labor market approach: is based on a comparison between expected employment rates and officially registered employment rates. Any difference found is the result of employment in the shadow economy [8].The cash transactions approach: which assumes that high tax rates stimulate tax evasion. This evasion is facilitated by the use of cash to conduct commercial transactions, so if it is demonstrated that a change in the use of cash is closely related to tax rates, this change can be considered an indicator of a change in the scope of hidden economic activity, and, therefore, the size of the hidden economy can be estimated on the basis of demand for cash [1].

One of the most popular methods for estimating the extent of tax evasion in various countries is the multiple indicators and multiple causes (MIMIC) model, which relies on the idea that the shadow economy is a variable that depends on multiple variables and has multiple indicators simultaneously. Thus, using the system of structural equations, it is possible to estimate the shadow economy and then the extent of tax evasion [9]. The currency demand approach (CDA): assumes that the desire to avoid paying taxes is the main reason for individuals and institutions tending to use cash instead of official bank accounts to conduct their commercial transactions. This method uses estimates of the demand for currency in the presence and absence of taxes. The purpose is to determine the size of the increase in the demand for currency that results from the presence of taxes in order to estimate the size of the shadow economy and then tax evasion [10].

This study is based on the related local and international empirical studies, such as the study of Alkhadour [11], which aimed to estimate the size of the shadow economy in Jordan during the period of 1976-2010. There is also the study of the Jordanian Economic and Social Council [12] that assessed tax evasion in Jordan applying several methodologies. The study also touched on the causes of tax evasion in Jordan and ways to reduce them. Another study with a similar interest is the study of Alghazo [13], which addressed the issue of the macroeconomic impacts of tax evasion in Jordan. At the level of international studies, the study of Bushra and Rauf [14] assessed the size of tax evasion in the Pakistani economy by estimating the shadow economy using the monetary approach. Moreover, Petanlar et al. [15] aimed to estimate the size of tax evasion in Iran during the period 1971-2007 through direct and indirect methods. 
Results showed that the size of tax evasion was on an increasing trend during that period. In addition, there is the study of Mehrara and Farahani [16] which dealt with the effects of tax evasion on tax stability in the OECD countries. The study of Medina and Schneider [17] estimated the shadow economy in 158 countries around the world, including Jordan during the period 1991-2015. It applied the (CDA) and (MIMIC) methodologies. Finally, the study of DiNola et al. [18] dealt with the overall consequences of tax evasion.

Regarding the most important factors that lead to tax evasion, many previous studies have shown that the idea of tax evasion begins with the taxpayer's sense of injustice that is concerned with the tax system as well as the fact that public resources, public goods, and public services are not fairly distributed among individuals, which increases the tendency towards tax evasion. The most important factors that reinforce the taxpayer's sense of injustice and the trend towards evasion are stated as follows:

Tax and Financial Factors: Some empirical studies conducted in various regions of the world have concluded that there is a positive and statistically significant effect of tax rates on tax evasion. Allingham and Sandmo [19] are among the pioneers who have concluded that cutting taxes and broadening the tax base have improved the tax compliance behaviors of taxpayers. Therefore, subsequent research has found that increasing tax rates leads to a higher tax burden on taxpayers and, thus, will ultimately prompt some taxpayers to adopt behaviors of tax evasion.

Administrative Factors: These are the factors linked to the tax system. For example, there are a large number of types of taxes, the lack of transparency and fairness, and the lack of tax penalties which are tough enough to ensure that legal accountability becomes a means of deterrence against tax evasion and encourages tax compliance provided that those penalties do not exceed the permissible limit. Spicer and Lundstedt [20] clarified that a potential increase in tax evasion penalties leads to a lower level of potential tax evasion behaviors. Other administrative factors include loopholes in tax laws, lack of auditor's reviews of tax returns, and low levels of knowledge, skills, and experience on the part of tax assessors and collectors.

Economic Factors (the Level and Components of Income): Fluctuations in taxpayers' incomes affect the decision to evade taxes, especially if these fluctuations are expected to increase and if they are compatible with the levels of political and economic power in a matter which would lead to corruption. In addition, the components of income play a major role in tax evasion, in the sense that evasion decreases if salaries and wages are declared, especially in the public sector. Furthermore, tax evasion increases if income is not declared, especially in the private sector.

Demographic Factors (Gender, Age, and Education): Demographic characteristics often affect the decision to evade taxes, and previous studies have shown that the motivation to evade taxes is higher among males than among females. With regard to age, it has been found that the elderly tend to be more compliant with taxes than young people, who tend to take risks and are less sensitive to the penalties for tax evasion. Moreover, a relationship has been found between the level of education and tax compliance, where tax evasion increases as educational levels decrease. In addition, it is higher in contexts where there is insufficient education about the tax system and its economic importance [21]. The rest of the research can be Illustrates by the flowchart in Figure 1.

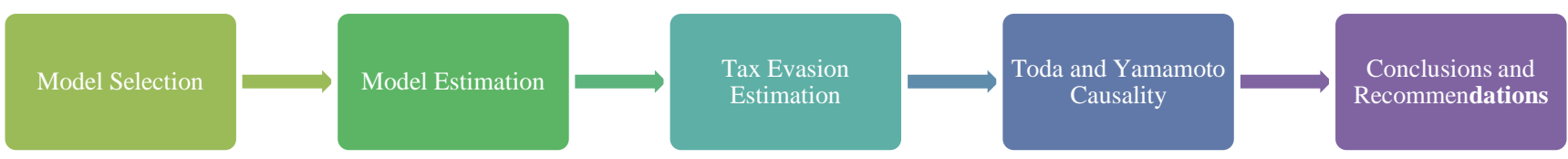

Figure 1. Flowchart of the research methodology.

\section{3- Methodology and Empirical Results of Estimating Tax Evasion}

This study relied on the (CDA) to estimate tax evasion in Jordan during the period 1980-2019. It used annual data issued by the Central Bank of Jordan, the General Budget Department, and the International Monetary Fund in the process of estimating the econometrics model for the study. This was based on the Tanzi model, which has been used in many studies, such as $[14,15,22,23]$. After considering some modifications to suit the Jordanian economy, results are shown as follows:

$$
D U C W_{t}=\beta_{0}+\beta_{1}(T R)_{t}+\beta_{2} P C_{t}+\beta_{3} R E M_{t}+\beta_{4} B R_{t}+\beta_{5}\left(R R_{t}\right)+\beta_{6}\left(R E X_{t}\right)+\beta_{5}(D U C)_{t-1}+\varepsilon_{t}
$$

Where (DUCW) is the ratio of the currency in circulation (CU) to the expanded money supply $\left(\mathrm{M}_{2}\right)$, $(\mathrm{TR})$ is the ratio of tax revenues to GDP, (PC) is the real GDP per capita, (REM) is the real remittances of workers from abroad, (BR) is the number of bank branches indicating financial development, (RR) is the real interest rate on time deposits, (REX) is the effective real exchange rate, $\left(\mathrm{DUC}_{\mathrm{t}-1}\right)$ is the demand for the currency in the previous period, and $(\varepsilon)$ is the random error limit.

Estimating tax evasion based on the (CDA) involved estimating the mentioned model and calculating the value of the ratio of the circulating currency to the expanded money supply $\left(D U C W_{t}\right)$. Then, it involved recalculating the ratio 
of the circulating currency to the expanded money supply but without considering any taxes in the model $\left(D U C W O_{t}\right)$ as well as finding the difference between them and, eventually, multiplying the difference by the expanded money supply $I M_{t}=\left(D U C W_{t}-D U C W O_{t}\right) \times M_{2 t}$ to estimate the illegal demand for money. This is because this approach assumes that an increase in the demand for the circulated currency occurs because the additional cash will be used to cover illegal commercial activities for the purposes of tax evasion since additional taxes have been imposed. The demand for legal money was calculated by subtracting the illegal money from the money supply $\left(L M_{t}=M_{1 t}-I M_{t}\right)$. Furthermore, the velocity of money $\left(V_{t}=G D P_{t} / L M_{t}\right)$ in the formal economy was calculated and considered equal to the velocity of money in the shadow economy and multiplied by the value of illegal money to obtain an estimate of the shadow economy $\left(S H E_{t}=V_{t} \times I M_{t}\right)$. Finally, it was assumed that the ratio of tax revenues to GDP in the shadow economy was the same as in the formal economy. This ratio was multiplied by the estimated size of the shadow economy to find an estimate for the extent of tax evasion (TE) during the study period.

Before taking the previous steps, some other calculations had been taken into consideration. First, the natural logarithm of the variables was taken in order to make the variables smoother. Second, it was necessary to establish the availability of the statistical stationarity required in the time series used in the estimation in order to obtain non-spurious estimates since most macroeconomic time series suffer from non-stationarity [24]. Through the results of the Augmented Dickey-Fuller (ADF) test presented in Table 1, it was found that some of the study variables were stationary at level $\mathrm{I}(0)$, and some were stationary on the first difference $I(1)$, so the Ordinary Least Squares (OLS) method could not be used. Nevertheless, the researchers were able to use the fully modified ordinary least squares method (FM-OLS) to obtain results that achieved the desired statistical characteristics of unbiased, efficiency, and consistency after establishing that there was a co-integration between the model variables.

Table 1. ADF Unit Root Test.

\begin{tabular}{|c|c|c|c|c|c|}
\hline Variable & Calculated value & Critical value & Lag Length & degree of stationary & Level of significance \\
\hline $\operatorname{LOG}(\mathrm{BR})$ & -5.55 & -2.63 & 0 & $\mathrm{I}(1) *$ & $1 \%$ \\
\hline LOG (RPC) & -2.99 & -2.95 & 1 & $\mathrm{I}(0) *$ & $5 \%$ \\
\hline LOG (RR) & -5.52 & -3.62 & 0 & $\mathrm{I}(1) * *$ & $1 \%$ \\
\hline LOG (REX) & -3.03 & -2.94 & 1 & $\mathrm{I}(0) * *$ & $5 \%$ \\
\hline
\end{tabular}

after applying the co-integration test based on the bounds test derived from the autoregressive distributed lag (ARDL) model developed by Pesaran et al. (2001) [25], and since the time series are non-stationary at the same degree, the results presented in Table 2 showed the existence of at least one vector for co-integration between the variables under study. This means that the variables of the model can change together over time. Thus, we were able to guarantee the existence of a relationship between those integrated variables.

Table 2. Bounds Co-integration Test.

\begin{tabular}{|c|c|c|c|c|c|c|}
\hline \multirow{3}{*}{ Model } & \multirow{3}{*}{ F-Calculated } & \multicolumn{4}{|c|}{ Critical Value Bounds } & \multirow{3}{*}{ Decision } \\
\hline & & \multicolumn{2}{|c|}{$5 \%$} & \multicolumn{2}{|c|}{$1 \%$} & \\
\hline & & Lower bound & Upper bound & Lower bound & Upper bound & \\
\hline$D U C=f(T R, P C, R E M, B R, R R, R E X)$ & 4.64 & 2.45 & 3.61 & 3.15 & 4.43 & $\begin{array}{c}\text { There is } \\
\text { co-integration }\end{array}$ \\
\hline
\end{tabular}

After the model was estimated by the FM-OLS method, the results in Table 3, were obtained. They showed that all the explanatory variables used in the model were statistically significant, and their variations could explain $90.3 \%$ of the variance that occurred in the ratio of the currency in circulation to the expanded money supply. The tax revenue (TR) coefficient was found to be positive, which indicates that an increase in the tax burden leads to an increase in the demand for currency in order to complete commercial operations in cash and to avoid registered banking operations for the purposes of tax evasion. The coefficient of the number of bank branches is negative, which means that an increase in the number of bank branches reduces the need to use cash because of the possibility of conducting some commercial operations through those bank branches. GDP per capita and remittances from workers abroad were found to have a positive effect as exchange operations and speculation operations increase among individuals who need more cash. The effective real exchange rate was found to have a positive effect on the demand for money as an increase in the exchange rate (a decrease in the value of the currency) indicates a need for a greater amount of money to complete commercial 
operations. Finally, the effect of the interest rate on the demand for money was negative because a higher interest rate means an increase in the opportunity cost of holding cash. This reduces the demand for money, especially when the market interest rate rises above the expected internal rate of return on investment.

Table 3. The results of estimating the demand equation for the circulation currency in the presence of tax.

\begin{tabular}{|c|c|c|c|}
\hline \multicolumn{4}{|c|}{ Dependent variable: LOG $\left(D U C W_{t}\right)$} \\
\hline Variable & Coefficient & T-Statistic & Prob. \\
\hline $\mathrm{C}$ & 0.750 & 3.68 & $1 \%$ \\
\hline$L O G(T R)_{t}$ & 0.071 & 13.14 & $1 \%$ \\
\hline $\operatorname{LOG}\left(N B_{t}\right)$ & -0.389 & -18.10 & $1 \%$ \\
\hline $\operatorname{LOG}\left(R P C_{t}\right)$ & 0.175 & 2.54 & $5 \%$ \\
\hline $\operatorname{LOG}\left(\operatorname{RREM}_{t}\right)$ & 0.077 & 18.38 & $1 \%$ \\
\hline $\operatorname{LOG}\left(R R_{t}\right)$ & -0.006 & 14.3 & $1 \%$ \\
\hline $\operatorname{LOG}\left(R E E X_{t}\right)$ & 0.141 & 9.8 & $1 \%$ \\
\hline$L O G(D U C)_{t-1}$ & 0.840 & 18.03 & $1 \%$ \\
\hline
\end{tabular}

After obtaining the antilog for the estimated model and applying all the steps of the currency demand method to estimate the size of tax evasion, as previously explained, the extent of tax evasion during the study period was obtained, as shown in Table 4.

Table 4. The estimated tax evasion size, Million dinars.

\begin{tabular}{cccccccc}
\hline Year & Tax Evasion & Year & Tax Evasion & Year & Tax Evasion & Year & Tax Evasion \\
\hline 1980 & - & 1990 & 56.358 & 2000 & 167.270 & 2010 & 561.257 \\
1981 & 34.315 & 1991 & 80.188 & 2001 & 195.898 & 2011 & 509.576 \\
1982 & 42.939 & 1992 & 101.975 & 2002 & 184.746 & 2012 & 537.915 \\
1983 & 45.775 & 1993 & 103.171 & 2003 & 166.232 & 2013 & 569.903 \\
1984 & 52.959 & 1994 & 114.825 & 2004 & 230.117 & 2014 & 609.506 \\
1985 & 54.689 & 1995 & 125.632 & 2005 & 243.294 & 2015 & 646.457 \\
1986 & 61.340 & 1996 & 149.395 & 2006 & 351.916 & 2016 & 613.928 \\
1987 & 54.755 & 1997 & 149.206 & 2007 & 460.681 & 2017 & 664.803 \\
1988 & 52.950 & 1998 & 162.414 & 2008 & 579.918 & 2018 & 738.151 \\
1989 & 53.214 & 1999 & 156.438 & 2009 & 569.575 & 2019 & 773.307 \\
\hline
\end{tabular}

Table 4, shows the estimated volume of tax evasion in the Jordanian economy. The results showed that, in the Jordanian economy, tax evasion amounted to about 34.3 million dinars in 1981, forming $15 \%$ of tax revenues and $2 \%$ of GDP. After that, it increased during the study period despite of the slight decrease in some years. Eventually, it reached 773.31 million dinars, forming $17 \%$ of tax revenues and $2.4 \%$ of GDP. The average rate of tax evasion for tax revenues during the entire study period was about $16.5 \%$, and the average percentage of GDP that tax forms was $2.7 \%$. These results are close to the results of previous studies that have been conducted on the Jordanian economy. Therefore, addressing the issue of tax evasion in economic policies and tax laws should be considered an important goal to control the phenomenon of tax evasion.

\section{4- Methodology and Empirical Results of Consequences of Tax Evasion}

There are many theoretical opinions and applied results regarding the economic and social consequences that result from the phenomenon of tax evasion, whether directly or indirectly, as a result of the correlations between most economic variables, these consequences are spread out to the economy as a whole.

The vast majority, especially officials and those in charge of the tax system and financial policies, consider the consequences of tax evasion generally negative. However, some individuals and institutions consider it to have some positive consequences, especially those related to provision of job opportunities, and opportunities for income generation, as the informal sector in the economy is regarded as an alternative way for some companies to enhance their competitiveness in the formal economy. This is because tax evasion reduces production costs since these companies do not bear any tax burdens. This improves their competitiveness at the local and international levels. In addition, most tax evasions are returned to the formal economy through the increasing household consumption of goods and services, 
which contributes to an increase in GDP and, thus, an increase in tax revenues; that is, tax evasion is considered, by some, to be one of the ways to reduce the effects of economic recession and high unemployment rates [26].

In this study, the issue of the consequences of tax evasion was addressed in relation to some macroeconomic variables, such as (GDP), consumer price index (CPI), tax revenues (TRE), public debt (DEB), interest rate (R), public consumption (PUCO), private consumption (PRCO), public investment (INVPU), and private investment (INVPV) through the causality relationship, due to the impact of the values of the estimated parameters and their statistical significance, when removing or adding any of the explanatory variables if the regression model was used, and it is not possible to address all the variables that may affect the phenomenon under study. Moreover, the volume of tax evasion is estimated and not actual, and this is why the causality test was chosen. The causality test is considered the preferred experimental approach to reveal the extent of a relationship between two or more variables, in comparison with the statistical correlation and regression approach. Granger was the first to introduce the concept of causation into econometrics in 1969, and Sims's 1972 study is regarded as the first study to apply Granger's methodology to causal relationships. In 1976, William, Goodhart, and Gowland applied Sim's model in the UK.

In 1983, both Granger and Weiss developed the general idea of co-integration as Granger proved that causal relationships exist between co-integration time series. This can be represented by the error correction model (ECM), which was introduced in 1985. In 1986, Granger presented a method to estimate and test the existence of a cointegrated relationship between groups of variables [27], but due to the lack of integration of some time series at the same degree, it is not always possible to use the traditional Granger method for testing causality, so a suitable causal test was developed for this purpose by Toda and Yamamoto. This test is known as the (TY) approach. It is derived from the classical vector autoregressive model (VAR) using optimal lag intervals $(\mathrm{k})$ that reduce the residual correlation. After lag intervals had been modified to become $(\mathrm{k}+\mathrm{dmax})$ instead of $\mathrm{k}$, where $(\mathrm{dmax})$ indicates the highest degree of stationarity of the variables using the unit root test, the causality of the autoregressive vector with $(\mathrm{K}+\mathrm{dmax})$ lag intervals were calculated [28].

Before conducting the causality test, the ADF test for stationarity was applied in order to establish the stationarity degree of the time series and to choose the appropriate causation approach. As shown in the results in Table 5, the time series are not stationary at the same degree. Moreover, it was found that some time series were stationary on the first difference and some were stationary on the second difference, so the TY causality test was adopted.

Table 5. Unit Root Tests.

\begin{tabular}{|c|c|c|c|c|c|}
\hline Variables & T-Statistic & Test-critical & Lag & integrated & Significant level \\
\hline $\mathrm{TE}$ & $-3.856 *$ & -3.62 & 0 & $\mathrm{I}(1)$ & $1 \%$ \\
\hline GDP & $-10.777 * * *$ & -2.63 & 0 & $I(2)$ & $1 \%$ \\
\hline CPI & -4.591 & -3.62 & 0 & $\mathrm{I}(1)$ & $1 \%$ \\
\hline TRE & $-3.784 * *$ & -3.584 & 2 & $\mathrm{I}(2)$ & $5 \%$ \\
\hline DEB & $-7.535 * * *$ & -2.63 & 0 & $\mathrm{I}(2)$ & $1 \%$ \\
\hline $\mathrm{R}$ & $-4.037^{*}$ & -3.621 & 0 & $\mathrm{I}(1)$ & $1 \%$ \\
\hline PUCO & $-10.683 * * *$ & -2.632 & 1 & $\mathrm{I}(1)$ & $1 \%$ \\
\hline PRCO & $-3.195 *$ & -2.943 & 0 & $\mathrm{I}(1)$ & $5 \%$ \\
\hline INVPU & $-6.353 * *$ & -4.23 & 1 & $\mathrm{I}(1)$ & $1 \%$ \\
\hline INVPV & $-10.432 *$ & -3.62 & 0 & $\mathrm{I}(1)$ & $1 \%$ \\
\hline
\end{tabular}

*: with intercept. **: with intercept and trend. ***: without intercept and trend.

Although there is no need for a co-integration test if the causal test (TY) is used, the test was applied using the bounds test. The results in Table 6 , show the existence of co-integration between the variables under study.

Table 6. Results of the co-integration test.

\begin{tabular}{|c|c|c|c|c|c|c|}
\hline \multirow{3}{*}{ Equation } & \multirow{3}{*}{ F-statistic } & \multicolumn{4}{|c|}{ Critical Value Bounds } & \multirow{3}{*}{ Decision } \\
\hline & & \multicolumn{2}{|c|}{$\% 1$} & \multicolumn{2}{|c|}{$\% 5$} & \\
\hline & & $\mathbf{I}(\mathbf{1})$ & $\mathbf{I}(\mathbf{0})$ & $\mathbf{I}(\mathbf{1})$ & $\mathbf{I}(\mathbf{0})$ & \\
\hline $\begin{array}{c}\text { TE }=\mathrm{f}(\mathrm{CPI}, \mathrm{TRE}, \mathrm{GDP}, \mathrm{DE} \text { B,PUCO, PRCO, R, } \\
\text { INVPV, INVPU) }\end{array}$ & 4.15 & 4.26 & 2.96 & 3.5 & 2.03 & There is co-integration \\
\hline
\end{tabular}

In order to determine the number of lag intervals required to eliminate the auto-correlation to the limit of the error, the number of appropriate time lag periods was determined based on the most reliable standards, including the Akaike Information Criterion (AIC), the Schwarz Criterion (SIC), the Hannan-Quinn (HQ) criterion, the Final Prediction Error (FBE), and the Likelihood Ratio (LR) test [29-30]. The results in Table 7 show that there are three periods of optimal lag. 
Table 7. Lag order selection criteria.

\begin{tabular}{ccccccc}
\hline Lag & LogL & LR & FPE & AIC & SC & 109.72 \\
\hline 0 & -1960.61 & NA & $4.34 \mathrm{e}+37$ & 109.37 & 98.46 & 96.39 \\
1 & -1643.21 & 476.10 & $3.64 \mathrm{e}+31$ & 95.29 & 92.40 & 98.38 \\
2 & -1527.17 & 122.49 & $3.56 \mathrm{e}+30$ & 94.49 & 93.02 & 87.30 \\
3 & -1316.08 & 128.10 & $7.01 \mathrm{e}+27$ & 84.27 & \\
\hline
\end{tabular}

Based on the results of the stationarity test given in Table 5, the value of dmax was determined to be 2 . By testing the number of appropriate lag intervals, the value of $\mathrm{k}=3$ was determined. Furthermore, it was determined that there was co-integration between the variables to establish the existence of a causal relationship, whether it is a unidirectional or bidirectional relationship, between the variables [31]. Then a causal test (TY) was performed, and the results are shown in Table 8.

Table 8. Toda and Yamamoto Causality Test.

\begin{tabular}{|c|c|c|c|c|}
\hline Null Hypothesis: & d.f & Chi-sq & Prob. & Decision \\
\hline TE does not Granger Cause CPI & 5 & 12.24 & 0.032 & reject the null hypothesis \\
\hline TE does not Granger Cause R & 5 & 1.419 & 0.841 & Can't reject the null hypothesis \\
\hline TE does not Granger Cause TRE & 5 & 9.657 & 0.085 & reject the null hypothesis \\
\hline TE does not Granger Cause GDP & 5 & 21.35 & 0.0007 & reject the null hypothesis \\
\hline TE does not Granger Cause DEB & 5 & 20.673 & 0.0009 & reject the null hypothesis \\
\hline TE does not Granger Cause PUCO & 5 & 20.664 & 0.0009 & reject the null hypothesis \\
\hline TE does not Granger Cause PRCO & 5 & 18.948 & 0.002 & reject the null hypothesis \\
\hline TE does not Granger Cause INVPV & 5 & 25.794 & 0.0001 & reject the null hypothesis \\
\hline TE does not Granger Cause INVPU & 5 & 7.625 & 0.178 & Can't reject the null hypothesis \\
\hline
\end{tabular}

The results of the causal test (TY) showed the consequences of tax evasion on some Jordanian economic variables after it had been demonstrated that there was a causal relationship between tax evasion and those economic variables, which we summarize as follows:

\section{The Existence of a Causal Relationship between Tax Evasion and the General Consumer Price Index:}

The existence of tax evasion indicates the inability of fiscal policy to achieve its objectives in absorbing the excess purchasing power of consumers by imposing taxes. This means the actual demand is not reduced and rebalanced with supply. This leads price levels to increase, or the government may resort to increasing tax rates or expanding the tax base because of its budget deficit. This in turn directly leads to an increase in the general price levels [32]. It was worth bearing in mind that price levels may sometimes be exaggerated as they are measured in the formal economy and not in the shadow economy, and price levels are often lower in the shadow economy because of tax evasion, as indicated in previous studies [26, 33, 34].

\section{The Existence of a Causal Relationship between Tax Evasion and Tax Revenues, Public Consumption, and Public} Investment:

Tax revenues are the main source of a country's revenue. However, with the spread of the tax evasion phenomenon, the informal economy will compete with the formal economy. The informal economy usually depends on goods smuggled from in or out of the state as well as on goods offered at lower prices than those in the formal economy. This affects a country's public revenues as smuggled goods are subject to neither taxes nor customs fees. As a country's actual tax revenues decline, this will be reflected in a decrease in the government expenditure, both current and capital, especially in the presence of a budget deficit. This was confirmed by the study of Folayan and Adeniyi's (2018) [35].

\section{The Existence of a Causal Relationship between Tax Evasion and Private Consumption:}

Due to the effect of tax evasion on the level of production, which is reflected in the income of the individual, tax evasion also leads to poor distribution of income between non-taxpayers and taxpayers, as non-taxpayers place an additional burden on committed taxpayers who form the majority. Consequently, the level of affluence in a society would be affected, and this is represented by the level of consumption.

\section{The Existence of a Causal Relationship between Tax evasion and Private Investment:}

Tax evasion increases cash available for individuals, which increases the demand for consumption goods, especially imported goods which are considered to be of better quality than local products. This leads to a decrease in the demand for local goods and, thus, affects the size of investment. In addition, tax evasion compromises the competition between local companies, which prevents tax-committed companies from surviving alongside tax-evading companies, and thus 
prompts their exit from the market. Furthermore, tax-evading companies keep their investments small so that they do not attract the attention of the tax administration. Therefore, they cannot expand nor can they integrate horizontally to achieve economies of scale, and this will be reflected in the size of private investment.

\section{The Existence of a Causal Relationship between Tax Evasion and GDP:}

It was shown previously how the spread of tax evasion affects the components of aggregate demand and forces the government to follow a contractionary fiscal policy by decreasing expenditure or rise the tax, which can be resulted in a weak level of savings. This limits investment capacity and affects economic growth. Thus, GDP will be reduced. This matches the findings of Cerqueti, and Raffaella [36].

\section{The Existence of a Causal Relationship between Tax Evasion and Public Debt:}

As a result of the decrease in the government's tax revenues and in the presence of a large public sector, the government expenditure cannot be significantly reduced, especially the current expenditure. This leads to a deficit in the government's budget, so the government resorts to making up the shortfall in revenue by increasing borrowing [35].

The study also noticed the absence of a causal relationship between tax evasion and the interest rate on time deposits despite of the expectations that there is a relationship between tax evasion and the interest rate. This could be explained in two ways:

1- Because of the government's low tax revenues and in the presence of a large public sector, it is not possible to dramatically reduce the government expenditure, especially the current expenditure, which leads to a deficit in the government budget [35]. Therefore, the government resorts to compensating for this lack of revenue by increasing borrowing. This leads to a competition with the private sector on loanable bank deposits, which results in an increase in the interest rate.

2- Tax evasion leads to an increase in the demand for cash. This occurs as a result of tax evaders avoiding commercial dealings other than those in cash, and if the increase in the demand for cash is not compensated for by an increase in the money supply, the interest rate increases. The apparent absence of a causal relationship between tax evasion and the interest rate may be because the effect takes time to appear as it is indirect.

Another expected economic consequence of tax evasion is the decrease in the quantity and quality of public services provided by the government. To illustrate, the increase in the trend towards tax evasion leaves the government unable to fulfill its obligations and responsibilities of improving the standards of living of its citizens, as a result of the decrease in its revenues. In addition, tax evasion presents moral and social issues, and it means that most official national accounts inaccurately represent the real performance of the economy. In particular, the increase in undeclared economic activities prevents the officially published GDP from representing the reality of the situation, rendering all economic indicators that are expressed as a percentage of GDP inaccurate. The budget deficit, the current account deficit, and public debt will be higher, as a percentage of GDP, than they would be if the real values of the shadow economy were reported. This leads to a misallocation of resources across sectors and improper economic policies that do not realize the reality of the situation. Moreover, the shadow economy will cause GDP per capita to appear artificially low, and this is often used as an indicator of the measured living standards in a country and as a benchmark for the comparison between different countries. In addition, the shadow economy leads to the failure to achieve the fair distribution of tax burdens and to the poor distribution of income across society as the behavior of non-taxpaying individuals increases the burden on taxpaying individuals, especially if the government is forced to increase tax rates. This affects the volume of private savings and consumption. The same situation is reflected in the performance of the economy as a whole [37,38]. Finally, tax evasion leads the companies that operate in the shadow economy to stay small, no matter how efficient they are, in order to remain undiscovered by the authorities, which is more difficult for large firms to do, and this prevents these firms from achieving the benefits of the economies of scale [36].

\section{5- Conclusions}

Based on the estimate of tax evasion produced in this research, we conclude that during the years addressed in the study there was an increase in tax evasion in the percentage calculated by GDP as well the percentage calculated by public revenues, despite of some variance during some years.

This may be attributed to the structure of the Jordanian economy, which is characterized by small investments, especially in non-productive sectors and services. Moreover, it is difficult to control such activities, register them, or collect taxes on their profits. This process has been made even more challenging by the high prices that have resulted from the depreciation of the national currency since 1989, the expansion in the tax base, the increases in tax rates, and the multiple changes in tax laws since 1989.

As for the effects of tax evasion on economic variables, the results of the (TY) causal test showed that there is a causal relationship between tax evasion and most macroeconomic variables, especially GDP and the general consumer price index. This is sufficient to spread the effect out to the other economic variables. Based on the results mentioned above, this study recommends that government authorities work to facilitate positive conditions for production and other 
economic activities, support local industries, and prohibit production and service activities that are not registered through legal means in order to be able to supervise their various banking operations. Government authorities should also pay more attention to tax collection departments. Furthermore, it is essential that the government works to adopt tax laws with optimal tax rates based on scientific studies and follows a modern and effective approach to tax collection by using modern technology in the applications of billing systems, in addition to reducing the complexities and ambiguities in tax laws and regulations as well as toughening penalties for tax evasion. This will encourage more individuals to pay taxes and, thus, prevents the increasing trend of tax evasion, which will be a step towards increasing government revenues.

Although the accuracy of the results of tax evasion assessment remains relative, as it is difficult to achieve the actual values of tax evasion due to the secrecy of the procedures carried out by the tax evaders, the estimation process remains useful in giving a picture of the size and the trends of tax evasion. Therefore, it would be beneficial in the future to conduct studies which assess the size of tax evasion, whether considering direct taxes or indirect taxes, make comparisons between them, and evaluate their effects on the economic variables.

\section{6- Declarations}

\section{6-1-Author Contributions}

Conceptualization, A.M.G., Q.M.Q. and Z.M.A.; writing—original draft preparation, A.M.G., Q.M.Q. and Z.M.A.; writing - review and editing, A.M.G., Q.M.Q. and Z.M.A.; All authors have read and agreed to the published version of the manuscript.

\section{6-2-Data Availability Statement}

The data presented in this study are available on request from the corresponding author.

\section{6-3- Funding}

The authors received no financial support for the research, authorship, and/or publication of this article.

\section{6-4-Conflicts of Interest}

The author declares that there is no conflict of interests regarding the publication of this manuscript. In addition, the ethical issues, including plagiarism, informed consent, misconduct, data fabrication and/or falsification, double publication and/or submission, and redundancies have been completely observed by the authors.

\section{7- References}

[1] Tanzi, Vito. "The underground economy in the United States: Annual estimates, 1930-80 (L'économie clandestine aux Etats-Unis: Estimations annuelles, 1930-80)(La" economía subterránea" de Estados Unidos: Estimaciones anuales, 1930-80)." Staff PapersInternational Monetary Fund (1983): 283-305. doi:10.2307/3867001.

[2] Dell'Anno, Roberto, and Adriana AnaMaria Davidescu. "Estimating Shadow Economy and Tax Evasion in Romania. A Comparison by Different Estimation Approaches." Economic Analysis and Policy 63 (September 2019): 130-149. doi:10.1016/j.eap.2019.05.002.

[3] Hyman, David N. Public finance: A contemporary application of theory to policy. Cengage Learning, 2014.

[4] Christians, Allison. "Distinguishing Tax Avoidance and Evasion." The Routledge Companion to Tax Avoidance Research (October 2, 2017): 417-429. doi:10.4324/9781315673745-26.

[5] MacAfee, Kerrick. "A Glimpse of the hidden economy in the national accounts." Economic Trends 136, no. 1 (1980): 81-87.

[6] Blades, Derek. "The hidden economy and national accounts." The OECD Observer 114 (1982): 15.

[7] Gupta, P., and R. Mehta. "An estimate of underreported national income." Journal of Income and Wealth 5, no. 2 (1981): 109113.

[8] Isachsen, Arne Jon, and Steiner Strom. "The Size and Growth of the Hidden Economy in Norway." Review of Income and Wealth 31, no. 1 (March 1985): 21-38. doi:10.1111/j.1475-4991.1985.tb00496.x.

[9] Dell'Anno, Roberto. “The Shadow Economy in Portugal: An Analysis with the Mimic Approach.” Journal of Applied Economics 10, no. 2 (November 2007): 253-277. doi:10.1080/15140326.2007.12040490.

[10] Cagan, Phillip. "The Demand for Currency Relative to the Total Money Supply." Journal of Political Economy 66, no. 4 (August 1958): 303-328. doi:10.1086/258056.

[11] Alkhdour, Rajeh. "Estimating the shadow economy in Jordan: causes, consequences, and policy implications." PhD diss., Colorado State University, 2012.

[12] Economic and Social Council. Tax Evasion in Jordan: Causes, Methods, and Magnitude, Amman, Jordan (2014). 
[13] Alghazo, abdalwahab, The macroeconomics impacts of tax evasion in Jordan, unpublished Doctoral Dissertation, unpublished Doctoral Dissertation, university of Jordan, Amman (2020).

[14] Yasmin, Bushra, and Hira Rauf. "Measuring the Underground Economy and Its Impact on the Economy of Pakistan." The Lahore Journal of Economics 9, no. 2 (July 1, 2004): 93-103. doi:10.35536/lje.2004.v9.i2.a5.

[15] Petanlar, Saeed Karimi. Ahmad Jafari Samimi, and. Alireza Aminkhaki. “An Estimation of Tax Evasion in Iran.” Journal of Economics and Behavioral Studies 3, no. 1 (July 15, 2011): 8-12. doi:10.22610/jebs.v3i1.250.

[16] Mehrara, Mohsen, and Yazdan Gudarzi Farahani. "The study of the effects of tax evasion and tax revenues on economic stabilities in OECD countries." World Scientific News 33 (2016): 43-55.

[17] Medina, Leandro, and Friedrich Schneider. "Shadow Economies Around the World: What Did We Learn Over the Last 20 Years?” IMF Working Papers 18, no. 17 (2018): 1. doi:10.5089/9781484338636.001.

[18] Di Nola, Alessandro, Georgi Kocharkov, Almuth Scholl, and Anna-Mariia Tkhir. "The Aggregate Consequences of Tax Evasion.” Review of Economic Dynamics 40 (April 2021): 198-227. doi:10.1016/j.red.2020.09.009.

[19] Allingham, Michael G., and Agnar Sandmo. "Income tax evasion: A theoretical analysis." Journal of public economics 1.3-4 (1972): 323-338. doi:10.1016/0047-2727(74)90037-1.

[20] Spicer, Michael W., and Scott B. Lundstedt. "Understanding tax evasion." Public Finance= Finances publiques 31.2 (1976): 295305.

[21] Ameyaw, Bismark, and Dominic Dzaka. "Determinants of Tax Evasion: Empirical Evidence from Ghana." Modern Economy 07, no. 14 (2016): 1653-1664. doi:10.4236/me.2016.714145.

[22] Ahmed, Mehnaz, and Qazi Masood Ahmed. "Estimation of the black economy of Pakistan through the monetary approach." The Pakistan Development Review 34, no. 4 (1995): 791-807.

[23] Kemal, M. Ali. "Underground economy and tax evasion in Pakistan: A critical evaluation." Working Papers \& Research Reports (2010): RR-No.

[24] Nelson, Charles R., and Charles R. Plosser. “Trends and Random Walks in Macroeconmic Time Series.” Journal of Monetary Economics 10, no. 2 (January 1982): 139-162. doi:10.1016/0304-3932(82)90012-5.

[25] Pesaran, M. Hashem, Yongcheol Shin, and Richard J. Smith. "Bounds Testing Approaches to the Analysis of Level Relationships.” Journal of Applied Econometrics 16, no. 3 (2001): 289-326. doi:10.1002/jae.616.

[26] Fishburn, Geoffrey. "Tax Evasion and Inflation.” Australian Economic Papers 20, no. 37 (December 1981): $325-332$. doi:10.1111/j.1467-8454.1981.tb00359.x.

[27] Engle, Robert F., and C. W. J. Granger. "Co-Integration and Error Correction: Representation, Estimation, and Testing." Econometrica 55, no. 2 (March 1987): 251. doi:10.2307/1913236.

[28] Toda, Hiro Y., and Taku Yamamoto. "Statistical Inference in Vector Autoregressions with Possibly Integrated Processes." Journal of Econometrics 66, no. 1-2 (March 1995): 225-250. doi:10.1016/0304-4076(94)01616-8.

[29] Greene, William H. Econometric analysis. Pearson Education India, 2003.

[30] Damodar, N. Gujarati. Basic Econometrics-Damodar N. Gujarati. McGraw- Hill, 2004.

[31] Bekhet, Hussain Ali, and Ali Matar. "Co-Integration and Causality Analysis between Stock Market Prices and Their Determinates in Jordan.” Economic Modelling 35 (September 2013): 508-514. doi:10.1016/j.econmod.2013.07.012.

[32] Hung, Fu-Sheng. "Explaining the Nonlinearity of Inflation and Economic Growth: The Role of Tax Evasion." International Review of Economics \& Finance 52 (November 2017): 436-445. doi:10.1016/j.iref.2017.03.008..

[33] Fishlow, Albert, and Jorge Friedman. “Tax Evasion, Inflation and Stabilization.” Journal of Development Economics 43, no. 1 (February 1994): 105-123. doi:10.1016/0304-3878(94)90025-6.

[34] Pablo Nicolini, Juan. "Tax Evasion and the Optimal Inflation Tax.” Journal of Development Economics 55, no. 1 (February 1998): 215-232. doi:10.1016/s0304-3878(97)00063-1.

[35] Folayan, D. O., and A. G. Adeniyi. "Effects of tax evasion on government revenue generation in Oyo State, Nigeria." European Journal of Accounting, Auditing and Finance Research 6, no. 1 (2018): 76-89.

[36] Cerqueti, Roy, and Raffaella Coppier. "Economic Growth, Corruption and Tax Evasion.” Economic Modelling 28, no. 1-2 (January 2011): 489-500. doi:10.1016/j.econmod.2010.07.006.

[37] Vousinas, Georgios L. "Shadow Economy and Tax Evasion. The Achilles Heel of Greek Economy. Determinants, Effects and Policy Proposals." Journal of Money Laundering Control 20, no. 4 (October 2, 2017): 386-404. doi:10.1108/jmlc-11-20160047.

[38] Cerqueti, Roy, and Raffaella Coppier. "Economic Growth, Corruption and Tax Evasion.” Economic Modelling 28, no. 1-2 (January 2011): 489-500. doi:10.1016/j.econmod.2010.07.006. 